\title{
Shewanella gelidimarina sp. nov. and Shewanella frigidimarina sp. nov., Novel Antarctic Species with the Ability To Produce Eicosapentaenoic Acid (20:5 23 ) and Grow Anaerobically by Dissimilatory Fe(III) Reduction
}

\author{
JOHN P. BOWMAN,,${ }^{1,2 *}$ SHAREE A. MCCAMMON, ${ }^{2}$ DAVID S. NICHOLS, ${ }^{1,2}$ \\ JENNY H. SKERRATT, ${ }^{1}$ SUZANNE M. REA,${ }^{3}$ PETER D. NICHOLS,${ }^{1,4}$ \\ AND TOM A. MCMEEKIN ${ }^{1,2}$ \\ Antarctic CRC, ${ }^{1}$ Institute for Antarctic and Southern Ocean Studies, ${ }^{3}$ and Department of Agricultural Science, ${ }^{2}$ \\ University of Tasmania, Sandy Bay, Hobart, Tasmania 7005, and CSIRO Marine Research Division, \\ Marine Laboratories, Castray Esplanade, Hobart, Tasmania, ${ }^{4}$ Australia
}

\begin{abstract}
A polyphasic taxonomic study was performed to characterize dissimilatory iron-reducing strains mostly isolated from Antarctic sea ice. The strains were isolated from samples of congelated (land-fast) sea ice, grease ice, and ice algal biomass collected from the coastal areas of the Vestfold Hills in eastern Antarctica $\left(68^{\circ} \mathrm{S}\right.$ $\left.7^{\circ} \mathrm{E}\right)$. The strains were facultatively anaerobic, motile, and rod shaped, were capable of anaerobic growth either by fermentation of carbohydrates or by anaerobic respiration, and utilized a variety of electron acceptors, including nitrate, ferric compounds, and trimethylamine $N$-oxide. A phylogenetic analysis performed with 16S rRNA sequences showed that the isolates formed two groups representing novel lineages in the genus Shewanella. The first novel group included seawater-requiring, psychrophilic, chitinolytic strains which had DNA $\mathrm{G}+\mathrm{C}$ contents of $48 \mathrm{~mol} \%$. The members of the second strain group were psychrotrophic and did not require seawater but could tolerate up to $9 \% \mathrm{NaCl}$. The strains of this group were also unable to degrade polysaccharides but could utilize a number of monosaccharides and disaccharides and had $\mathbf{G}+\mathrm{C}$ contents of 40 to $43 \mathrm{~mol} \%$. The whole-cell-derived fatty acid profiles of the sea ice isolates were found to be similar to the profiles obtained for other Shewanella species. The omega-3 polyunsaturated fatty acid eicosapentaenoic acid (EPA) (20:5 03 ) was detected in all of the sea ice isolates at levels ranging from 2 to $16 \%$ of the total fatty acids. EPA was also found at high levels in Shewanella hanedai (19 to 22\%) and Shewanella benthica (16 to 18\%) but was absent in Shewanella alga and Shewanella putrefaciens. On the basis of polyphasic taxonomic data, the Antarctic iron-reducing strains are placed in two new species, Shewanella frigidimarina sp. nov. (type strain, ACAM 591) and Shewanella gelidimarina sp. nov. (type strain, ACAM 456).
\end{abstract}

The genus Shewanella includes facultatively anaerobic, gram-negative, motile, rodlike cells. The original member of the genus, now called Shewanella putrefaciens, was first isolated from rancid butter by Derby and Hammer (8), who designated it "Achromobacter putrefaciens." Long and Hammer (19) later renamed this taxon "Pseudomonas putrefaciens." The difference in DNA G+C contents between typical members of the genus Pseudomonas and "Pseudomonas putrefaciens" prompted Baumann et al. (1) to reclassify this species as " $\mathrm{Al}$ teromonas putrefaciens." Finally, the genus Shewanella, including the species Shewanella putrefaciens, Shewanella benthica, and Shewanella hanedai, was created by MacDonell and Colwell (22) following a 5S rRNA sequence analysis. S. benthica includes barophilic isolates obtained from marine fauna collected from the deep ocean (5-7). S. hanedai, a bioluminescent species, was isolated from marine sediment and was originally described as "Alteromonas hanedai" (15). More recent additions to the genus Shewanella include Shewanella colwelliana and Shewanella alga. S. colwelliana (4), which initially was classified as "Alteromonas colwelliana" (43), was isolated from the oyster Crassostrea virginica. A tetrodotoxin-producing strain isolated from red algae (Jainia sp.) was named $S$. alga (39), and the description of this taxon was later emended by Nozue et al.

* Corresponding author. Mailing address: Antarctic CRC, University of Tasmania, GPO Box 252-80, Hobart, Tasmania 7001, Australia. Phone: 61036226 2776. Fax: 61036226 2642. E-mail: john.bowman @antcrc.utas.edu.au.
(32). More recently, $16 \mathrm{~S}$ rRNA sequence-based phylogenetic analyses of Shewanella species $(12,37)$ indicated that the genus was most closely related to [Vibrio] marinus (brackets indicate a generically misclassified species), Ferrimonas balearica, Pseudoalteromonas spp., and Colwellia psychroerythus.

In this study a number of strains were isolated from sea ice obtained from Antarctic coastal sites and from cyanobacterial mats and waters of Antarctic meromictic lakes. These isolates were found to form two distinct phenetic groups (2) and were able to grow anaerobically by dissimilatory iron reduction. A polyphasic taxonomic analysis demonstrated that these groups represent distinct and novel species in the genus Shewanella, and we propose the names Shewanella frigidimarina sp. nov. and Shewanella gelidimarina sp. nov. for these taxa.

\section{MATERIALS AND METHODS}

Isolation and bacterial strains. Antarctic samples were collected during the 1992 to 1995 summer seasons from locations around the Vestfold Hill ice-free zone on the southern Prydz Bay coast in eastern Antarctica. Grease ice samples were collected from surface waters. Congelation (land-fast) sea ice cores were obtained by using a SIPRE ice drill (diameter, $7 \mathrm{~cm}$ ) and on the same day were melted in sterile seawater at $4^{\circ} \mathrm{C}$. Ice-derived algal material was collected by filtration through $0.8-\mu \mathrm{m}$-pore-size nitrocellulose filters. Algal material derived from breakout from ice, accumulating at the shoreline of Ace Lake (Vestfold Hills), was also collected. All samples were plated onto marine 2216 agar (Difco Laboratories, Detroit, Mich.). Plates were incubated at either 4 or $25^{\circ} \mathrm{C}$ for up to 2 months. This work was performed as part of a general survey of the bacterial diversity of Antarctic sea ice (2), and in this investigation a number of strains with a phenotype similar to the phenotype of the genus Shewanella were isolated (Table 1). All strains investigated in this study were routinely grown on marine 
TABLE 1. Strains examined in this study

\begin{tabular}{|c|c|c|}
\hline Species & Strain $^{a}$ & Source \\
\hline S. alga & $\operatorname{ACAM} 541^{\mathrm{T}}\left(=\operatorname{ATCC} 51192^{\mathrm{T}}\right)$ & Red calcareous alga (Jania sp.) \\
\hline S. benthica & ACAM $543(=$ ATCC 43991) & $\begin{array}{l}\text { Digestive tract, amphipod (Scopolocheirus shellengi), } \\
\text { Puerto Rico Trench }\end{array}$ \\
\hline S. benthica & $\operatorname{ACAM} 544^{\mathrm{T}}\left(=\operatorname{ATCC} 43992^{\mathrm{T}}\right)$ & $\begin{array}{l}\text { Intestine, holothurian (Psychrobotes longicauda), } \\
\text { Walvis Ridge, South Atlantic Ocean }\end{array}$ \\
\hline S. hanedai & $\operatorname{ACAM} 540^{\mathrm{T}}\left(=\operatorname{ATCC} 33224^{\mathrm{T}}\right)$ & Marine sediment, Arctic Ocean \\
\hline S. hanedai & ACAM 585 & Congelation ice, Ellis Fjord, Antarctica \\
\hline S. putrefaciens & ACAM $574(=$ NCIMB 8768) & Machine oil emulsion \\
\hline S. putrefaciens & ACAM $575^{\mathrm{T}}\left(=\right.$ ATCC $8071^{\mathrm{T}}=$ NCIMB $\left.10471^{\mathrm{T}}\right)$ & Rancid butter \\
\hline S. putrefaciens & ACAM $576(=$ ATCC $8072=$ NCIMB 10472) & Butter with surface taint \\
\hline S. putrefaciens & ACAM $577(=$ ATCC $8073=$ NCIMB 10473) & Butter with surface taint \\
\hline S. gelidimarina & ACAM $456^{\mathrm{T}}$ & Congelation ice, Prydz Bay, Antarctica \\
\hline S. gelidimarina & ACAM 586 & Congelation ice, Ellis Fjord, Antarctica \\
\hline S. frigidimarina & ACAM 122 & Pycnocline, Burton Lake, Antarctica \\
\hline S. frigidimarina & ACAM 584 & Cyanobacterial mat, Ace Lake, Antarctica \\
\hline S. frigidimarina & ACAM 587 & Congelation ice, Prydz Bay, Antarctica \\
\hline S. frigidimarina & ACAM 588 & Congelation ice, Prydz Bay, Antarctica \\
\hline S. frigidimarina & ACAM 589 & Grease ice, Ellis Fjord, Antarctica \\
\hline S. frigidimarina & ACAM 590 & Congelation ice, Prydz Bay, Antarctica \\
\hline S. frigidimarina & ACAM $591^{\mathrm{T}}$ & Congelation ice, Prydz Bay, Antarctica \\
\hline S. frigidimarina & ACAM 592 & Grease ice, Ellis Fjord, Antarctica \\
\hline S. frigidimarina & ACAM 593 & Grease ice, Ellis Fjord, Antarctica \\
\hline S. frigidimarina & ACAM 594 & Grease ice, Ellis Fjord, Antarctica \\
\hline S. frigidimarina & ACAM 595 & Cyanobacterial mat, Ace Lake, Antarctica \\
\hline S. frigidimarina & ACAM 596 & Cyanobacterial mat, Ace Lake, Antarctica \\
\hline S. frigidimarina & ACAM 597 & Cyanobacterial mat, Ace Lake, Antarctica \\
\hline S. frigidimarina & ACAM 598 & Ice algal biomass, Ellis Fjord, Antarctica \\
\hline S. frigidimarina & ACAM 599 & Congelation ice, Prydz Bay, Antarctica \\
\hline S. frigidimarina & ACAM 600 & Congelation ice, Prydz Bay, Antarctica \\
\hline S. frigidimarina & ACAM 601 & Ice algal biomass, Ellis Fjord, Antarctica \\
\hline
\end{tabular}

${ }^{a}$ ACAM, Australian Collection of Antarctic Microorganisms, Antarctic CRC, University of Tasmania, Hobart, Tasmania, Australia; ATCC, American Type Culture Collection, Rockville, Md.; NCMB, National Collection of Marine Bacteria, Aberdeen, Scotland, United Kingdom.

2216 agar. All of the Antarctic isolates and $S$. hanedai were incubated at $10^{\circ} \mathrm{C} . S$. benthica strains were incubated at $4^{\circ} \mathrm{C}$. S. alga and $S$. putrefaciens were cultivated at $25^{\circ} \mathrm{C}$.

Phenotypic characterization. Gram stain, oxidase, and catalase tests were performed as previously described (41). Motility was determined by microscopically examining cell wet mounts. Seawater requirement and tolerance to various $\mathrm{NaCl}$ concentrations ( 0 to $12 \%$ ) were tested on nutrient agar (Oxoid, Ltd. Basingstoke, United Kingdom). Starch hydrolysis test plates were prepared similarly, and hydrolysis activity was detected by flooding the plates with a $1 \%$ (wt/vol) iodine solution. Tween 80 hydrolysis, egg yolk hydrolysis, esculin hydrolysis, and casein hydrolysis were tested as described by Smibert and Krieg (41) DNA hydrolysis was tested by using DNase test agar (Oxoid). Chitin hydrolysis and alginate hydrolysis were tested as described by West and Colwell (44) in media prepared with artificial seawater. In tests for acid production from carbohydrates we used the oxidation-fermentation medium of Leifson (18). Dissimilatory iron reduction was tested in a seawater medium adapted from the medium described by Widdel and Bak (45) and prepared by using the Hungate technique (13). The medium contained $10 \mathrm{mM}$ amorphic ferric oxide-neutralized ferric chloride or $10 \mathrm{mM}$ soluble ferric oxide-ferric pyrophosphate (21) as the electron acceptors, and $10 \mathrm{mM}$ sodium acetate or sodium DL-lactate was used as the electron donor. Uninoculated controls lacking the iron electron donor were also prepared. Iron reduction was confirmed by the appearance of a black precipitate (magnetite) and by the Merckoquant iron test (Merck). Anaerobic growth with $20 \mathrm{mM}$ potassium nitrate and $10 \mathrm{mM}$ trimethylamine $N$-oxide (TMAO) was tested in a medium containing (per liter of artificial seawater) $2 \mathrm{~g}$ of ammonium chloride and $2 \mathrm{ml}$ of trace element solution SL-10 (33) and $2 \mathrm{mM}$ potassium phosphate buffer ( $\mathrm{pH} 7.0$ ). The medium $\mathrm{pH}$ was adjusted to 7.0 with $1 \mathrm{M} \mathrm{KOH}$, and the medium was solidified with $1.3 \%(\mathrm{wt} / \mathrm{vol})$ purified agar (Oxoid). Sodium acetate and sodium DL-lactate were each added at a concentration of $20 \mathrm{mM}$. Plates were incubated in an anaerobic jar by using anaerogaspaks (Oxoid). Growth on the plates was compared with growth on control plates lacking electron acceptors. Additional biochemical tests were performed with an API 20E test kit (BioMerieux, Lyon, France), which was prepared according to the manufacturer's specifications except that bacterial strains were suspended in chilled artificial seawater. For carbon and energy source screening we added most of the test compounds at a concentration of $0.1 \%$ (wt/vol); the exceptions were the carbohydrates, which were tested at a concentration of $0.2 \%$ (wt/vol). The basal medium used was the same medium utilized for the nitrate and TMAO electron donor experiments described above. Media lacking a car- bon source were prepared as negative controls to account for any background growth.

Growth rate analysis. The growth rates of strains ACAM $456^{\mathrm{T}}$ and ACAM $591^{\mathrm{T}}$ were determined in a temperature gradient incubator (Toyo, Inc., Tokyo, Japan). The temperatures used ranged from 0 to $40^{\circ} \mathrm{C}$, and tubes containing 10 $\mathrm{ml}$ of marine 2216 broth were inoculated with $0.5 \mathrm{ml}$ of cells taken from cultures in the late logarithmic growth phase. Growth was measured by determining the decrease in transmittance at $550 \mathrm{~nm}$ for up to 14 days. A culture was considered positive for growth if the culture transmittance increased by more than $20 \%$. The data were fitted to the Ratkowsky square root temperature growth model (36), and cardinal growth temperatures were determined.

Whole-cell fatty acid analysis. Representative strains were grown on marine 2216 agar at $10^{\circ} \mathrm{C}$ for 2 to 4 days, harvested by scraping into a small amount of artificial seawater, and then washed by centrifugation in artificial seawater. The pellets were lyophilized prior to solvent extraction with a vacuum freeze drier (Dynavac, Melbourne, Victoria, Australia). Whole-cell fatty acid profiles were quantitatively determined by using gas chromatography and gas chromatography-mass spectrometry (30). The geometry and position of double bonds in monounsaturated fatty acids were confirmed by using dimethyl disulfide derivatization and by performing an analysis in which gas chromatography-mass spectrometry (31) was used. The double bond positions were numbered from the methyl $(\omega)$ end of the fatty acid.

Genotypic analysis. Genomic DNA was extracted and purified from cells (grown in the same way as the cells used for the fatty acid analysis were grown) by using the procedure of Marmur and Doty (23). The DNA G+C content was then determined from thermal denaturation profiles (40).

DNA-DNA hybridization. A spectrophotometric renaturation rate kinetic procedure as adapted by Huss et al. (14) was used to determine levels of DNA-DNA reassociation between genomic DNAs of different strains. Genomic DNA was sheared to an average size of $1 \mathrm{~kb}$ by sonication and dialyzed overnight at $4^{\circ} \mathrm{C}$ in $2 \times \mathrm{SSC}(0.3 \mathrm{M} \mathrm{NaCl}$ plus $0.03 \mathrm{M}$ sodium citrate, $\mathrm{pH} 7.0)$, and the concentration was adjusted to approximately $60 \mu \mathrm{g} / \mathrm{ml}$. Following denaturation of the DNA samples, hybridization was performed at the optimal temperature for renaturation $\left(T_{\mathrm{OR}}\right)$, which was $25^{\circ} \mathrm{C}$ below the DNA melting temperature and was calculated from the following equation: $T_{\mathrm{OR}}=48.5+(0.41 \times \mathrm{G}+\mathrm{C}$ content $)$ (24). The declines in absorbance over a 40-min interval for DNA mixtures and control DNA samples were used to calculate DNA hybridization values from the following equation (14): $\%$ DNA hybridization $=[4 A B-A-B / 2 \sqrt{ }(A \times B)] \times$ $100 \%$, where $A$ and $B$ are the changes in absorbance for the two DNA samples 
being compared and $A B$ is the change in absorbance for an equimolar mixture of $A$ and $B$. DNA hybridization values equal to or less than $25 \%$ were thought to represent background hybridization and thus were not considered significant (14).

Phylogenetic analysis. The $16 \mathrm{~S}$ rRNA sequence was determined for the following strains: $S$. gelidimarina ACAM $456^{\mathrm{T}}$; $S$. frigidimarina ACAM 122, ACAM 584, ACAM 587, ACAM 591 ${ }^{\mathrm{T}}$, ACAM 593, and ACAM 600; and strain ACAM 586. The $16 \mathrm{~S}$ rRNA genes from these strains were amplified by PCR by using primers $27 \mathrm{fM} 13 \mathrm{f}$ ( $5^{\prime}$-TGTAAAACGACGGCCAGTAGAGTTTGATCCTGGC TCAG-3') and 1492rM13r (5'-TACGGYTACCTTGTTACGACTTCAGGAA ACAGCTATGACC $-3^{\prime}$ ), in which the -21 M13 forward and M13 reverse sites were combined with $16 \mathrm{~S}$ rRNA primers $9-27 \mathrm{f}$ and $1492-1512 \mathrm{r}$, respectively. The conditions used for the PCR have been described by Dobson et al. (9). The amplicons were purified by using a QiaQuick PCR purification kit. The $16 \mathrm{~S}$ rRNA sequences were then generated by using dye primer cycle sequencing ready reaction $-21 \mathrm{M} 13$ forward and M13 reverse kits and a model A377 automated DNA sequencer (Applied Biosystems, Foster City, Calif.). The sequence data were manually aligned with Shewanella 16S rRNA sequences and the 16S rRNA sequences of related species. Software from PHYLIP, version $3.57 \mathrm{c}(10)$, was used to further analyze the sequence data set. DNADIST, with the maximum-likelihood option, was employed to determine sequence similarities, and NEIGHBOR was used to create a phylogenetic tree. Bootstrap analysis (with 1,000 replicates) was used to determine the branching proportions within the phylogenetic tree by using the programs SEOBOOT and CONSENSE.

Nucleotide sequence accession numbers. Sequences of the following organisms (with GenBank accession numbers in parentheses) were utilized in the phylogenetic analysis and were obtained directly from GenBank: Colwellia psychroerythrus ACAM 550 (AF001365) (2), F. balearica DSM 9799 ${ }^{\mathrm{T}}$ (X93021) (38), Pseudoalteromonoas haloplanktis ATCC 14393 ${ }^{\mathrm{T}}$ (X67024) (12), S. benthica ACAM 544 ${ }^{\mathrm{T}}$ (X82131) (9), S. hanedai ACAM 540 ${ }^{\mathrm{T}}$ (X82132) (12), S. putrefaciens ATCC $8071^{\mathrm{T}}$ (X82123) (12), Shewanella (barophilic) sp. strain DB172R (D63824) (17), [V.] marinus NCIMB $1144^{\mathrm{T}}$ (X82142) (12), and barophilic or barotolerant strains DB6705 (D21222), DB6906 (D21223), DSK1 (D21224), DSS12 (D21225), and DB5501 (D21229) (16). 16S rRNA sequences of the following strains were obtained in this study and were deposited in GenBank (accession numbers are given in parentheses): $S$. alga ACAM 541 ${ }^{\mathrm{T}}$ (AF006669); $S$. frigidimarina ACAM 122 (U39399), ACAM 584 (U85902), ACAM 588 (U85905), ACAM 591 ${ }^{\mathrm{T}}$ (U85903), ACAM 593 (U85904), and ACAM 600 (U85906); S. gelidimarina ACAM 456 ${ }^{\mathrm{T}}$ (U85907); $S$. hanedai ACAM 585 (U85907); and $S$. putrefaciens ACAM 574 (AF006670), ACAM 576 (AF006671), and ACAM 577 (AF006672).

\section{RESULTS}

Isolation and growth characteristics. The isolates formed circular, tan-pigmented colonies 2 to $4 \mathrm{~mm}$ in diameter on marine 2216 agar following 3 to 5 days of incubation at $10^{\circ} \mathrm{C}$. After approximately 7 days of incubation at $10^{\circ} \mathrm{C}$, the colonies lost their opacity and became increasingly mucoid. The isolates could be readily divided into two groups based on their inherent ecophysiology and represent two novel species of the genus Shewanella, S. gelidimarina sp. nov. and $S$. frigidimarina sp. nov., which are described below.

S. frigidimarina strains (Table 1) were isolated either directly from sea ice or from cyanobacterial mats and the water columns and ice of marine salinity lakes, such as Ace Lake and Burton Lake. One strain (ACAM 122) was isolated from the pycnocline of Burton Lake during a previous study of that lake's microbiota (11). S. frigidimarina strains grew at temperatures between $<0$ and 27 to $28^{\circ} \mathrm{C}$, while no growth occurred at $30^{\circ} \mathrm{C}$. The optimal growth temperature was 20 to $22^{\circ} \mathrm{C}$. This species does not require sodium ions or other seawater-derived cations for growth and tolerates a maximum $\mathrm{NaCl}$ concentration of 8 to $9 \%$ (wt/vol). The growth of the type strain, ACAM 591 , was not stimulated by adding $1 \%$ (wt/vol) $\mathrm{NaCl}$ or seawater to sodium-free media.

$S$. gelidimarina included two strains, ACAM $456^{\mathrm{T}}$ and ACAM 585 (Table 1), which were isolated from platelet ice layers of ice cores collected from the Ellis Fjord area of the Vestfold Hills coast (2). Both strains grew optimally at 15 to $17^{\circ} \mathrm{C}$, and no growth occurred at temperatures above $23^{\circ} \mathrm{C}$. Both strains required seawater for growth. The $S$. gelidimarina strains failed to grow on media containing less than $20 \%$ sea- water or $1 \% \mathrm{NaCl}$ but grew on marine agar prepared with up to $2 \times$ artificial seawater or on nutrient agar (Difco) supplemented with up to $6 \% \mathrm{NaCl}$. Neither $S$. frigidimarina nor $S$. gelidimarina required vitamins for growth, and both organisms were able to utilize inorganic nitrogen sources, such as ammonium chloride and potassium nitrate.

Phenotypic characterization. S. frigidimarina, $S$. gelidimarina, $S$. alga and $S$. putrefaciens were able to grow anaerobically by reducing nitrate, TMAO, and ferric compounds while using DL-lactate or acetate as an electron donor. This was shown by positive growth or stimulation of growth when the strains were incubated anaerobically in media containing the electron acceptors compared to media which lacked the electron donors. TMAO and nitrate reduction but not iron reduction could be used for anaerobic growth by $S$. benthica ACAM 543 and $S$. hanedai ACAM 540 ${ }^{\mathrm{T}}$ and ACAM 585. Anaerobic growth by fermentation of carbohydrates was also observed with some Shewanella species. S. frigidimarina, S. gelidimarina, S. hanedai, and $S$. benthica could ferment D-glucose and/or $N$-acetylglucosamine. Neither $S$. alga nor $S$. putrefaciens can grow anaerobically via fermentation of carbohydrates. Fermentation of carbohydrates by Shewanella species was accompanied by acid production, but no gas was observed.

The Antarctic Shewanella isolates were strongly proteolytic and lipolytic, as are most other Shewanella strains (1, 42-44). Neither S. frigidimarina nor S. gelidimarina hydrolyzed starch, but $S$. gelidimarina was strongly chitinolytic (Table 2 ). This species, as well as $S$. benthica, could grow anaerobically by fermentation of chitin with concomitant acid production. $S$. frigidimarina was able to oxidatively produce acid from a broader range of carbohydrates than other Shewanella species (Table 2).

DNA base compositions. The overall DNA base composition range for Shewanella species ranges from 40 to $54 \mathrm{~mol} \%$ (see Table 5). S. frigidimarina strains have $\mathrm{G}+\mathrm{C}$ contents ranging from 40 to $43 \mathrm{~mol} \%$ (average, $41.0 \pm 1.6 \mathrm{~mol} \% ; n=11$ ), while S. gelidimarina ACAM $456^{\mathrm{T}}$ and ACAM 586 have $\mathrm{G}+\mathrm{C}$ contents of $48 \mathrm{~mol} \%$ (Table 2). ACAM 585 has a G+C content of $43.8 \mathrm{~mol} \%$, which falls within the range that is typical of $S$. hanedai (1).

DNA-DNA hybridization. DNA-DNA hybridization data are shown in Table 3. Representative strains of $S$. frigidimarina had DNA reassociation values ranging from 68 to $96 \%$. The level of DNA hybridization between $S$. gelidimarina ACAM $456^{\mathrm{T}}$ and ACAM 586 was $84 \%$. S. frigidimarina strains exhibited low DNA homology levels with $S$. putrefaciens ACAM $575^{\mathrm{T}}$ (range, 27 to $43 \%$; average, $37 \% \pm 6 \%$ ) (Table 3). S. gelidimarina likewise exhibited a low level of DNA hybridization with $S$. benthica ACAM $544^{\mathrm{T}}$ (Table 3). Strain ACAM 585 had a DNA hybridization level of $70 \%$ with the genomic DNA of $S$. hanedai ACAM $540^{\mathrm{T}}$. Based on this level of DNA reassociation, ACAM 585 definitively is a member of the species $S$. hanedai.

Phospholipid fatty acid analysis. The major fatty acids of

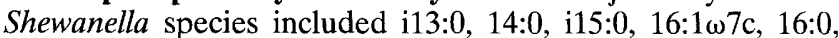
and $17: 1 \omega 8 \mathrm{c}$ (Table 4$)$. The polyunsaturated fatty acid eicosapentaenoic acid (EPA) $(20: 5 \mathrm{\omega} 3)$ was also a significant constituent of the whole-cell fatty acids of $S$. benthica, $S$. hanedai, $S$. gelidimarina, and $S$. frigidimarina (Table 4). EPA was absent from the strains of $S$. alga and $S$. putrefaciens examined in this study.

16S rRNA phylogenetic analysis. The 16S rRNA genes of $S$. frigidimarina ACAM 122, ACAM 584, ACAM 587, ACAM $591^{\mathrm{T}}$, ACAM 593, and ACAM 600, S. gelidimarina ACAM $456^{\mathrm{T}}$ and ACAM 585, $S$. hanedai ACAM 585, $S$. alga ACAM $541^{\mathrm{T}}$, and $S$. putrefaciens ACAM 574, ACAM 576, and ACAM 577 were 1,420 to 1,510 nucleotides long and extended from 
TABLE 2. Phenotypic characteristics of $S$. gelidimarina sp. nov. and $S$. frigidimarina sp. nov.

\begin{tabular}{|c|c|c|}
\hline Characteristic & S. frigidimarina & S. gelidimarina \\
\hline \multicolumn{3}{|l|}{ Cardinal temp } \\
\hline Optimum temp $\left({ }^{\circ} \mathrm{C}\right)$ & $20-22$ & $15-17^{a}$ \\
\hline Maximum temp $\left({ }^{\circ} \mathrm{C}\right)$ & $25-27$ & $23^{a}$ \\
\hline Minimum temp $\left({ }^{\circ} \mathrm{C}\right)$ & -14 & $-26^{a}$ \\
\hline Seawater requirement (stenohaline) & $-{ }^{b}$ & + \\
\hline Tolerance to $8 \% \mathrm{NaCl}$ & + & - \\
\hline \multicolumn{3}{|l|}{ Hydrolysis of: } \\
\hline Chitin & - & + \\
\hline DNA & + & $\mathrm{v}+$ \\
\hline L-Tyrosine & $\mathrm{v}-$ & - \\
\hline ONPG test & $v-$ & - \\
\hline Ornithine decarboxylase & $v-$ & - \\
\hline Arginine dihydrolase & $v-$ & - \\
\hline $\mathrm{H}_{2} \mathrm{~S}$ production (from thiosulfate) & $\mathrm{v}+$ & + \\
\hline Simmons citrate tests & $v+$ & - \\
\hline \multicolumn{3}{|l|}{ Fermentation of: } \\
\hline D-Glucose & + & - \\
\hline$N$-Acetylglucosamine & - & + \\
\hline \multicolumn{3}{|l|}{ Oxidative acid production from: } \\
\hline $\begin{array}{l}\text { Cellobiose, maltose, D-mannitol, } \\
\text { sucrose }\end{array}$ & + & - \\
\hline Trehalose & $\mathrm{v}+$ & - \\
\hline D-Galactose, D-mannose, D-xylose & $v-$ & - \\
\hline \multicolumn{3}{|l|}{$\begin{array}{l}\text { Utilization of the following compounds } \\
\text { as sole carbon and energy sources: }\end{array}$} \\
\hline L-Glutamate & $v-$ & + \\
\hline $\mathrm{N}$-Acetylglucosamine & - & + \\
\hline $\begin{array}{l}\text { Cellobiose, D-glucose, maltose, } \\
\text { sucrose, trehalose, mannitol, } \\
\text { propionate, isobutyrate, succinate, } \\
\text { fumarate, L-malate, oxaloacetate, } \\
\text { L-leucine }\end{array}$ & + & - \\
\hline $\begin{array}{l}\text { Nonanoate, L-phenylalanine, L- } \\
\text { proline }\end{array}$ & $v+$ & - \\
\hline $\begin{array}{l}\text { D-Fructose, D-galactose, D-xylose, } \\
\text { glycogen, caproate, L-glutamate, } \\
\text { hydroxy-L-proline, } \gamma \text { - } \\
\text { aminobutyrate }\end{array}$ & $v-$ & - \\
\hline $\mathrm{G}+\mathrm{C}$ content $(\mathrm{mol} \%)^{c}$ & $40-43$ & 48 \\
\hline
\end{tabular}

\footnotetext{
${ }^{a}$ Data from reference 30.

$b-, 0$ to $10 \%$ of the strains are positive;,$+ 90 \%$ or more of the strains are positive; $\mathrm{v}+, 11$ to $89 \%$ of the strains are positive and the type strain is positive; $\mathrm{v}-, 11$ to $89 \%$ of the strains are positive and the type strain is negative. The following tests were positive for all of the strains studied: growth at $0^{\circ} \mathrm{C}$; growth with $0.5 \times$ to $2 \times$ seawater; tolerance to $0.0075 \% \mathrm{KCN}$ and $5 \%$ ox bile salts; hydrolysis of gelatin, casein, and Tween 80 ; lecithinase activity (egg yolk reaction); catalase and cytochrome $c$ oxidase activities; nitrate reduction; anaerobic growth by dissimilatory reduction of nitrate, TMAO, and Fe(III) with acetate and DL-lactate as electron donors; and utilization of acetate, butyrate, valerate, DL-lactate, and pyruvate as sole sources of carbon and energy. The following tests were negative for all of the strains studied: growth with $4 \times$ seawater; requirement for yeast extract and vitamin growth factors; lysine decarboxylase activity; L-phenylalanine and L-tryptophan deaminase activities; indole production from L-tryptophan; hydrolysis of alginate, esculin, urate, xanthine, urea, and starch; acid production from L-arabinose, L-rhamnose, lactose, D-melibiose, D-melezitose, D-raffinose, dextran, adonitol, $m$-inositol, D-sorbitol, and glycerol; and utilization of L-arabinose, lactose, D-raffinose, L-rhamnose, L-arabitol, $i$-erythritol, $m$-inositol, D-sorbitol, glycerol, $\alpha$-glycerophosphate, D-gluconate, D-glucuronate, isovalerate, heptanoate, caprylate, malonate, adipate, glutarate, pimelate, azelate, $t$-aconitate, citrate, 2-oxoglutarate, DL-3-hydroxybutyrate, L-alanine, $\mathrm{L}$-aspartate, L-asparagine, L-histidine, L-ornithine, L-serine, L-threonine, putrescine, and urate as sources of carbon and energy.

${ }^{c} \mathrm{G}+\mathrm{C}$ contents were determined by the thermal denaturation method.
}

nucleotide positions 5 to 1510 (Escherichia coli equivalent numbering). These sequences were compared with the sequences of other Shewanella species, closely related bacteria, such as F. balearica, $[V$.$] marinus, Pseudoalteromonas spp., and$
Colwellia psychroerythrus, and an assortment of barophilic or barotolerant strains examined in other studies $(6,16,17) . S$. frigidimarina formed a clade which had levels of sequence dissimilarity ranging from 0.2 to $1.7 \%$. The most divergent strain was the Burton Lake isolate, ACAM 122. The species most closely related to $S$. frigidimarina was $S$. putrefaciens (level of dissimilarity, $3.4 \% \pm 0.3 \%$ ), and these two species formed a common branch on the phylogenetic tree (bootstrap value, 100\%) (Fig. 1). 16S rRNA sequences of strains representing the four DNA-DNA hybridization groups of $S$. putrefaciens, as determined by Owen et al. (34), were also obtained in this study to confirm that $S$. frigidimarina was a taxonomically distinct entity. S. putrefaciens ACAM 574 and ACAM $575^{\mathrm{T}}$ (DNA hybridization group I), ACAM 576 (group II), and ACAM 577 (group III) were closely related to each other, exhibiting levels of dissimilarity of only 0.5 to $2.4 \%$. DNA hybridization group IV of $S$. putrefaciens has been recognized previously as being equivalent to $S$. alga (32). The $16 \mathrm{~S}$ rRNA sequence of $S$. alga ACAM $541^{\mathrm{T}}$ is closely related to the $S$. alga FeRed sequence (37), exhibiting a level of dissimilarity of $1.5 \%$, and $S$. alga clearly represents a distinct lineage within the genus $S h$ ewanella (Fig. 1). Barotolerant strain SC2A, which was isolated from California coastal waters (6) at a depth of about $2,000 \mathrm{~m}$, is also closely related to $S$. frigidimarina (Fig. 1), suggesting that this species may be cosmopolitan and occur throughout cold marine ecosystems.

S. gelidimarina ACAM $456^{T}$ was most closely related to $S$. benthica and various barophilic strains closely related to $S$. benthica at dissimilarity values of $3.6 \% \pm 0.2 \%$. On average, the $16 \mathrm{~S}$ rRNA of ACAM $456^{\mathrm{T}}$ and the $16 \mathrm{~S}$ rRNAs of other Shewanella species were $5.6 \% \pm 0.5 \%$ dissimilar. The assumption that ACAM 585 is a strain of $S$. hanedai was supported by the similarity of its 16S rRNA sequence and the 16S rRNA sequence of $S$. hanedai ACAM $540^{\mathrm{T}}$ (level of dissimilarity, $1.2 \%$ ) (Fig. 1).

\section{DISCUSSION}

The genus Shewanella has been the focus of a variety of studies owing to the versatile metabolism of this genus and the

TABLE 3. DNA-DNA hybridization between Antarctic isolates and a number of Shewanella strains

\begin{tabular}{|c|c|c|c|}
\hline \multirow[b]{2}{*}{ Strain } & \multicolumn{3}{|c|}{$\%$ DNA-DNA hybridization with ${ }^{a}$ : } \\
\hline & $\begin{array}{l}\text { S. frigidimarina } \\
\text { ACAM 591 }\end{array}$ & $\begin{array}{l}\text { S. gelidimarina } \\
\text { ACAM } 456^{T}\end{array}$ & $\begin{array}{c}\text { S. putrefaciens } \\
\text { ACAM } 575^{\mathrm{T}}\end{array}$ \\
\hline S. frigidimarina ACAM 122 & 76 & & 38 \\
\hline S. frigidimarina ACAM 584 & 69 & & \\
\hline S. frigidimarina ACAM 589 & 96 & & 42 \\
\hline S. frigidimarina ACAM 590 & 65 & & \\
\hline S. frigidimarina ACAM $591^{\mathrm{T}}$ & 100 & 16 & 38 \\
\hline S. frigidimarina ACAM 593 & 86 & & 43 \\
\hline S. frigidimarina ACAM 598 & 94 & & 36 \\
\hline S. frigidimarina ACAM 600 & 68 & & 27 \\
\hline S. gelidimarina ACAM $456^{\mathrm{T}}$ & 16 & 100 & 11 \\
\hline S. gelidimarina ACAM 586 & & 90 & \\
\hline S. benthica ACAM $544^{\mathrm{T}}$ & 19 & 36 & \\
\hline S. hanedai ACAM $540^{\mathrm{T} b}$ & 9 & 28 & 20 \\
\hline S. alga ACAM $541^{\mathrm{T}}$ & 21 & 20 & 12 \\
\hline S. putrefaciens ACAM $575^{\mathrm{T}}$ & 38 & 11 & 100 \\
\hline
\end{tabular}

a The standard deviations for DNA-DNA hybridization values ranged from 5 to $15 \%$. Triplicate analyses were performed.

${ }^{b} S$. hanedai ACAM $540^{\mathrm{T}}$ and ACAM 585 have a DNA-DNA hybridization value of $70 \%$. 
TABLE 4. Fatty acid compositions of Shewanella species

\begin{tabular}{|c|c|c|c|c|c|c|}
\hline \multirow[b]{2}{*}{ Fatty acid } & \multicolumn{6}{|c|}{$\%$ in: } \\
\hline & $\begin{array}{l}\text { S. frigidimarina } \\
(n=8)^{a}\end{array}$ & $\begin{array}{l}S, \text { gelidimarina } \\
(n=2)^{b}\end{array}$ & $\begin{array}{l}\text { S. benthica } \\
(n=2)\end{array}$ & $\begin{array}{l}\text { S. hanedai } \\
(n=2)\end{array}$ & $\begin{array}{c}S . \text { putrefaciens } \\
(n=3)\end{array}$ & $\begin{array}{l}\text { S. alga } \\
(n=1)\end{array}$ \\
\hline $12: 0$ & $0-1.8$ & $0.3-0.7$ & $0.2-1.4$ & $0.1-0.4$ & $0.1-2.6$ & 0.1 \\
\hline i13:0 & $3.1-8.3$ & $5.4-15.8$ & $2.8-8.9$ & $5.1-7.7$ & $1.0-3.6$ & 0.5 \\
\hline $13: 0$ & $0-0.4$ & $\operatorname{tr}-1.3^{c}$ & $0-0.3$ & $0-0.3$ & $0-0.5$ & 0.1 \\
\hline i14:0 & $0-1.0$ & $0.1-0.6$ & $0.7-1.0$ & $0.1-0.4$ & $\operatorname{tr}-0.3$ & 0.8 \\
\hline $14: 1 \omega 7 \mathrm{c}$ & $0.4-1.8$ & $0.3-0.8$ & $0.1-0.5$ & $0-\operatorname{tr}$ & $0-\operatorname{tr}$ & $\operatorname{tr}$ \\
\hline $14: 0$ & $2.7-4.1$ & $3.8-4.4$ & $11.0-11.9$ & $7.6-10.1$ & $1.5-5.9$ & 0.7 \\
\hline $\mathrm{i} 15: 0$ & $5.6-10.7$ & $8.3-11.6$ & $4.4-6.2$ & $7.9-8.2$ & $8.8-24.2$ & 17.8 \\
\hline $15: 0$ & $1.7-2.9$ & $1.6-6.7$ & $0.4-0.9$ & $2.9-3.5$ & $1.4-7.5$ & 4.0 \\
\hline $15: 1 \omega 8 \mathrm{c}$ & $0.3-1.3$ & $0.7-1.7$ & & $0-0.1$ & $0-0.7$ & $\operatorname{tr}$ \\
\hline $15: 1 \omega 6 c$ & $0-2.2$ & $0.4-1.7$ & $0-0.2$ & $0-0.5$ & $0-0.3$ & $\operatorname{tr}$ \\
\hline i16:0 & & & & & $0-\operatorname{tr}$ & 1.1 \\
\hline $16: 1 \omega 9 \mathrm{c}$ & $0-4.0$ & $0-0.7$ & & & $0-2.4$ & \\
\hline $16: 1 \omega 7 \mathrm{c}$ & $37.6-55.1$ & $27.4-37.0$ & $24.0-43.9$ & $25.0-33.1$ & $25.2-31.4$ & 16.3 \\
\hline $16: 1 \omega 7 \mathrm{t}$ & $0-1.4$ & $0-0.1$ & & & $1.0-1.7$ & 0.2 \\
\hline $16: 0$ & $4.5-16.9$ & $6.4-11.1$ & $10.6-11.6$ & $12.2-15.0$ & $27.9-31.0$ & 13.3 \\
\hline $\mathrm{i} 17: 0$ & $0-0.6$ & $0.1-0.4$ & $0.1-1.5$ & $0.8-2.4$ & $\operatorname{tr}-1.6$ & 0.5 \\
\hline $17: 1 \omega 8 \mathrm{c}$ & $1.7-3.7$ & $1.9-4.2$ & $1.6-6.6$ & $0.5-1.5$ & $2.7-3.7$ & 14.7 \\
\hline $17: 1 \omega 6 \mathrm{c}$ & & $0.8-0.9$ & $0-1.2$ & $0.3-0.5$ & $0-0.4$ & 1.4 \\
\hline $17: 0$ & $0.2-2.0$ & $0.4-0.5$ & $0.5-8.1$ & $0.6-1.0$ & $0.6-1.6$ & 4.6 \\
\hline $18: 1 \omega 9 \mathrm{c}$ & $0.2-2.8$ & $0.3-0.9$ & $0-0.2$ & $0.2-0.8$ & $1.1-3.6$ & 6.0 \\
\hline $18: 1 \omega 7 \mathrm{c}$ & $3.1-6.6$ & $1.0-8.4$ & $0-1.7$ & $2.2-3.7$ & $2.4-3.9$ & 7.2 \\
\hline $18: 1 \omega 7 \mathrm{t}$ & $0-1.2$ & & & & & 0.2 \\
\hline $18: 0$ & $0-0.2$ & $0.1-0.2$ & $0-0.5$ & $0-0.4$ & $0.5-3.2$ & 2.7 \\
\hline $18: 2 \omega 6$ & & & & & $0.1-2.2$ & \\
\hline $18: 4 \omega 3$ & $0-1.1$ & $\operatorname{tr}-0.3$ & & & & \\
\hline $20: 4 \omega 3$ & $0-0.4$ & $0.3-0.8$ & & & & \\
\hline $20: 5 \omega 3$ & $1.7-6.8$ & $11.7-16.0$ & $15.8-18.5$ & $19.2-22.2$ & & \\
\hline Other & $0.2-0.8$ & $0-0.2$ & & $0-0.3$ & $0-0.8$ & 2.7 \\
\hline
\end{tabular}

${ }^{a} n$ is the number of strains examined

${ }^{b}$ Includes data from reference 30 .

${ }^{c} \operatorname{tr}, \operatorname{trace}(<0.1 \%)$

diversity of niches from which Shewanella species have been isolated. For example, $S$. putrefaciens has been found to be exceptionally versatile in the range of electron acceptors which it can use for anaerobic respiration; these electron acceptors include ferric compounds, manganese oxide, molybdenum ox- ide, sulfur compounds, and nitrate $(20,21,26)$. Dissimilatory iron reduction has also been observed in $S$. alga and the phylogenetically closely related organism $F$. balearica $(37,38)$. Shewanella strains have the ability to anaerobically dehalogenate chlorinated compounds, such as tetrachloroethane (35),

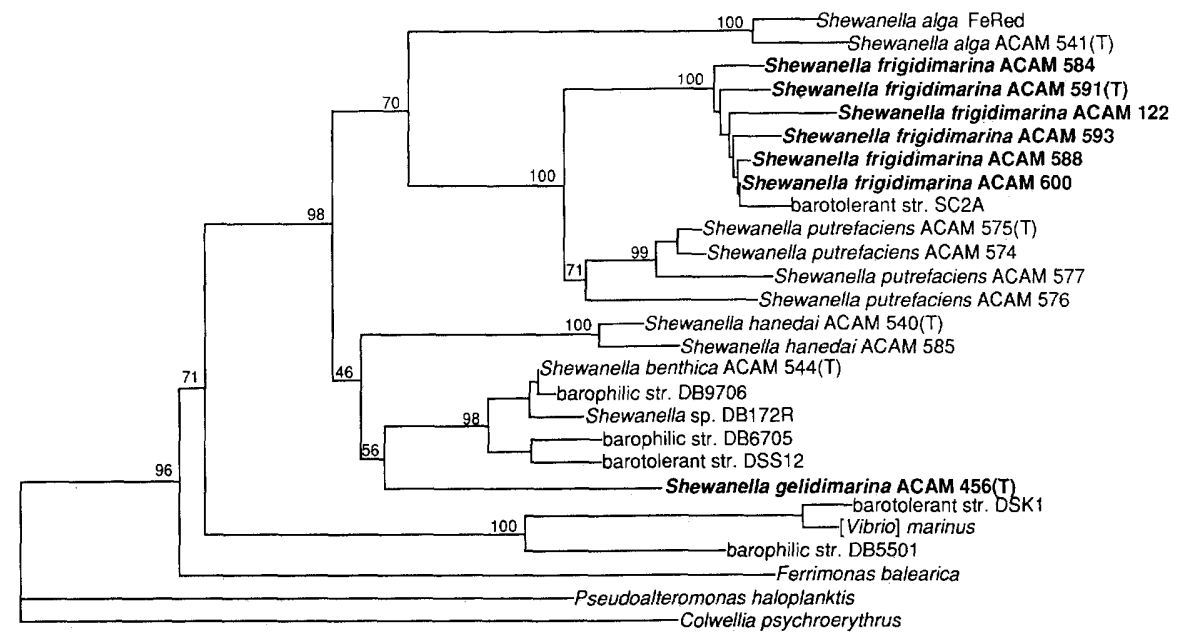

FIG. 1. Unrooted phylogenetic tree based on 16S rRNA comparisons, showing the taxonomic positions of $S$. frigidimarina and $S$. gelidimarina within the genus Shewanella. The branching pattern was generated by neighbor-joining methods, and bootstrap values (shown at the nodes) were calculated from 1,000 trees. Bar $=$ sequence dissimilarity of $3 \%$. 
TABLE 5. Characteristics that differentiate Shewanella species $^{a}$

\begin{tabular}{|c|c|c|c|c|c|c|c|c|c|c|c|c|}
\hline \multirow{2}{*}{ Species } & \multicolumn{2}{|c|}{ Growth at: } & \multirow{2}{*}{$\begin{array}{l}\text { Growth in the } \\
\text { presence of } \\
8 \% \mathrm{NaCl}\end{array}$} & \multirow{2}{*}{$\begin{array}{l}\text { Seawater } \\
\text { required }\end{array}$} & \multicolumn{3}{|c|}{ Production of: } & \multicolumn{2}{|c|}{ Fermentation of: } & \multirow{2}{*}{$\begin{array}{l}\text { Dissimilatory } \\
\text { Fe(III) } \\
\text { reduction }\end{array}$} & \multirow{2}{*}{$\begin{array}{c}\text { Synthesis of } \\
\text { EPA }\end{array}$} & \multirow{2}{*}{$\begin{array}{l}\mathrm{G}+\mathrm{C} \text { content } \\
\quad(\mathrm{mol} \%)\end{array}$} \\
\hline & $25^{\circ} \mathrm{C}$ & $30^{\circ} \mathrm{C}$ & & & Chitinase & Amylase & $\begin{array}{c}\text { Ornithine } \\
\text { decarboxylase }\end{array}$ & D-Glucose & $\begin{array}{l}N \text {-Acetyl- } \\
\text { glucosamine }\end{array}$ & & & \\
\hline S. gelidimarina & - & - & - & + & + & - & - & - & + & + & + & 48 \\
\hline$S$. frigidimarina & + & - & + & - & - & - & $\mathrm{v}$ & + & - & + & + & $40-43$ \\
\hline S. benthica & - & - & - & $+^{b}$ & + & - & - & + & + & $\mathrm{v}$ & + & 47 \\
\hline S. hanedai & - & - & - & $+^{c}$ & + & + & - & - & - & - & + & $43-44$ \\
\hline S. putrefaciens & + & + & - & - & - & - & + & - & - & + & - & $44-47$ \\
\hline S. alga & + & + & + & + & - & - & + & - & - & + & - & $53-54$ \\
\hline S. colwelliana & + & + & - & + & - & + & - & - & - & $\mathrm{ND}^{d}$ & ND & 46 \\
\hline
\end{tabular}

a Data from references $1,2,4,22,32,39,42$, and 43 and this study.

${ }^{b} S$. benthica requires a vitamin(s) for growth.

${ }^{c} S$. hanedai requires yeast extract for growth.

${ }^{d} \mathrm{ND}$, no data available.

are major spoilers of food $(25,42)$, and occasionally are found to cause bacteremias in humans (3). 16S rRNA-based phylogenetic analysis indicates that the psychrophilic, barophilic or barotolerant, deep-sea bacteria $(6,7,16,17)$ are closely related to $S$. benthica or $[V$.$] marinus (Fig. 1).$

In the present study, it was found that strains which were isolated from Antarctic sympagic and lacustrine environments and were phenotypically similar to Shewanella species (2) could grow anaerobically by dissimilatory iron reduction, as well as by carbohydrate fermentation. Phenotypic analysis also showed that these isolates formed two distinct ecophysiological groups, one which was psychrotrophic and nonhalophilic and one which was psychrophilic and slightly halophilic. Phenotypically, these groups did not closely resemble any of the previously recognized Shewanella species (Table 2) and could be differentiated from other species of the genus Shewanella by a number of characteristics, as shown in Table 5.

Genotypic analysis demonstrated that these groups represent distinct taxa since only low levels of DNA reassociation were found between the Antarctic strains and other Shewanella species (Table 3 ). This conclusion was also supported by $16 \mathrm{~S}$ rRNA phylogenetic studies, which showed that $S$. frigidimarina and $S$. gelidimarina form distinct lineages within the genus Shewanella (Fig. 1).

The lipid profiles of the Antarctic strains closely resemble the lipid profiles of other Shewanella species (27) except for the levels of EPA, the synthesis of which appears to be species specific. EPA and other polyunsaturated fatty acids are believed to maintain the homeoviscosity of cellular membranes, making them more permeable in cold and high-pressure environments (29). In the case of the genus Shewanella, the synthesis of EPA appears to be more prevalent in species with low temperature optima, particularly $S$. hanedai and $S$. benthica (optimum temperatures, $\sim 10^{\circ} \mathrm{C}$ ). With increasing temperature optima EPA levels decline, and $S$. frigidimarina strains (optimum temperatures, 20 to $22^{\circ} \mathrm{C}$ ) produce the lowest levels (Table 4). The fatty acid profiles of EPA-producing barophilic strains isolated from deep-sea locations (5) are similar to those of some Shewanella species, and these strains may be strains of $S$. benthica. No data are available for $S$. colwelliana, and $S$. putrefaciens and $S$. alga, which have mesophilic temperature optima $\left(>30^{\circ} \mathrm{C}\right)$, do not form EPA.

In conclusion, in this study we demonstrated that sea ice and other Antarctic habitats harbor two novel species of the genus Shewanella. The proposed names of these species are $S$. frigidimarina sp. nov. and $S$. gelidimarina sp. nov.

Description of Shewanella frigidimarina sp. nov. Shewanella frigidimarina (fri.gid.i.ma.ri'na. L. adj. frigidus, cold; L. fem. adj. marina, of the sea; M. L. adj. frigidimarina, of the cold sea). $S$. frigidimarina cells are rod shaped and either curved or straight (length, 1.0 to $2.5 \mu \mathrm{m}$; width, 0.5 to $0.8 \mu \mathrm{m}$ ) and occur singly or in pairs. Cells are motile. Facultatively anaerobic chemoheterotroph. Anaerobic growth occurs by fermentation of D-glucose or alternatively by anaerobic respiration with ferric compounds, nitrate, or TMAO as the electron acceptor and either sodium lactate or sodium acetate as the electron donor. Psychrotrophic. Growth occurs at temperatures from $<0$ to 27 to $28^{\circ} \mathrm{C}$. Optimal growth occurs at 20 to $22^{\circ} \mathrm{C}$. Nonhalophilic. Tolerates up to $9 \% \mathrm{NaCl}$. Growth factors are not required. Uses inorganic and organic nitrogen sources. Catalase and oxidase positive. Proteolytic and lipolytic. DNase is formed. May hydrolyze esculin and produce hydrogen sulfide from thiosulfate. A few strains show weak positive reactions in the $o$-nitrophenyl- $\beta$-D-galactopyranoside (ONPG), arginine dihydrolase, and ornithine decarboxylase tests. Amylase and chitinase are not produced. Acid is formed oxidatively from cellobiose, D-glucose, maltose, D-mannitol, and sucrose. Acid may also be formed from D-galactose, D-mannose, trehalose, and $\mathrm{D}$-xylose. No acid is produced from L-arabinose, $N$-acetylglucosamine, D-adonitol, glycerol, $m$-inositol, or D-sorbitol. The following carbon sources are utilized by all strains: cellobiose, D-glucose, maltose, sucrose, trehalose, D-mannitol, acetate, propionate, butyrate, isobutyrate, valerate, succinate, fumarate, DL-lactate, L-malate, pyruvate, oxaloacetate, and Lleucine. Strains may also use D-fructose, D-galactose, D-xylose, caproate, nonanoate, L-glutamate, L-phenylalanine, hydroxy-Lproline, L-proline, and $\gamma$-aminobutyrate. Produces EPA. The $\mathrm{G}+\mathrm{C}$ content of the DNA ranges from 40 to $43 \mathrm{~mol} \%$ (as determined by the thermal denaturation method). Strains have been isolated from sea ice, sea ice algal biomass, cyanobacterial mats, and the water columns of marine salinity meromictic lakes in Antarctica. The type strain is ACAM 591, which was isolated from Antarctic sea ice.

Description of Shewanella gelidimarina sp. nov. Shewanella gelidimarina (ge.lid.i.ma.ri'na. L. adj. gelidus, ice-cold; L. fem. adj. marina, of the sea; M. L. adj. gelidimarina, of the ice-cold or icy sea). Cells are rod shaped and either curved or straight (length, 1.5 to $2.5 \mu \mathrm{m}$; width, 0.5 to $0.8 \mu \mathrm{m}$ ) and occur singly or in pairs. Cells are motile. Facultatively anaerobic chemoheterotroph. Anaerobic growth occurs by fermentation of $N$ acetylglucosamine and chitin (but not D-glucose) or alternatively by anaerobic respiration with ferric compounds, nitrate, or TMAO as the electron acceptor and either sodium lactate or sodium acetate as the electron donor. Psychrophilic. Growth occurs at temperatures from $<0$ to $23^{\circ} \mathrm{C}$. Optimal growth occurs at 15 to $17^{\circ} \mathrm{C}$. Requires seawater for optimal growth. 
Growth occurs in media supplemented with $\mathrm{NaCl}$ at concentrations ranging from 1 to $6 \%$. Growth factors are not required. Uses inorganic and organic nitrogen sources. Catalase and oxidase positive. Chitinolytic, proteolytic, and lipolytic. Hydrogen sulfide is formed from thiosulfate. May produce DNase. Esculin and starch hydrolysis, ONPG, arginine dihydrolase, and ornithine decarboxylase tests are negative. Acid is formed oxidatively from $N$-acetylglucosamine. No acid is produced from L-arabinose, cellobiose, D-fructose, D-galactose, D-glucose, D-mannose, maltose, sucrose, trehalose, D-xylose, D-adonitol, glycerol, $m$-inositol, D-mannitol, or D-sorbitol. The following carbon sources are utilized: $N$-acetylglucosamine, acetate, propionate, butyrate, valerate, DL-lactate, pyruvate, and L-glutamate. Produces EPA. The $\mathrm{G}+\mathrm{C}$ content of the DNA is $48 \mathrm{~mol} \%$ (as determined by the thermal denaturation method). The type strain is ACAM 456, which was isolated from Antarctic sea ice.

\section{ACKNOWLEDGMENTS}

This work was supported by grants from the Antarctic Science Advisory Committee and from the Australian Research Council.

We thank Carol Mancuso (Australian Collection of Antarctic Microorganisms) for preservation of the strains and Peter Green (National Collection of Industrial and Marine Bacteria, Ltd.) and Phyllis Pienta (American Type Culture Collection) for providing reference cultures.

\section{REFERENCES}

1. Baumann, L., P. Baumann, M. Mandell, and R. D. Allen. 1972. Taxonomy of aerobic marine eubacteria. J. Bacteriol. 110:402-409.

2. Bowman, J. P., S. A. McCammon, M. V. Brown, D. S. Nichols, and T. A. McMeekin. 1997. Diversity and association of psychrophilic bacteria in Antarctic sea ice. Appl. Environ. Microbiol. 63:3068-3078.

3. Brink, A. J., A. Vanstraten, and A. J. Vanrensberg. 1995. Shewanella (putrefaciens) bacteremia. Clin. Infect. Dis. 20:1327-1332.

4. Coyne, V. E., C. J. Pillidge, D. D. Sledjeski, H. Hori, B. A. Ortiz-Conde, D. G. Muir, R. M. Weiner, and R. R. Colwell. 1989. Reclassification of Alteromonas colwelliana to the genus Shewanella by DNA:DNA hybridization, serology and 5S ribosomal RNA sequence data. Syst. Appl. Microbiol. 12:275-279.

5. DeLong, E. F., and A. A. Yayanos. 1986. Biochemical function and ecological significance of novel bacterial lipids in deep-sea procaryotes. Appl. Environ. Microbiol. 51:730-737.

6. DeLong, E. F., D. G. Franks, and A. A. Yayanos. 1997. Evolutionary relationships of cultivated psychrophilic and barophilic deep-sea bacteria. Appl. Environ. Microbiol. 63:2105-2108.

7. Deming, J. W., H. Hada, R. R. Colwell, K. R. Luehrsen, and G. E. Fox. 1984. The ribonucleotide sequence of $5 \mathrm{~S}$ rRNA from two strains of deep-sea barophilic bacteria. J. Gen. Microbiol. 130:1911-1920.

8. Derby, H. A., and B. W. Hammer. 1931. Bacteriology of butter. IV. Bacteriological studies on surface taint butter. Iowa Agric. Exp. Stn. Res. Bull. 145:389-416.

9. Dobson, S. J., R. R. Colwell, T. A. McMeekin, and P. D. Franzmann. 1993. Direct sequencing of the polymerase chain reaction-amplified 16S rRNA gene of Flavobacterium gondwanense sp. nov. and Flavobacterium salegens sp. nov., two new species from a hypersaline Antarctic lake. Int. J. Syst. Bacteriol. 43:77-83

10. Felsenstein, J. 1993. PHYLIP (phylogeny inference package), version $3.57 \mathrm{c}$. University of Washington, Seattle.

11. Franzmann, P. D., P. P. Deprez, A. J. McGuire, T. A. McMeekin, and H. R Burton. 1990. The heterotrophic bacterial microbiota of Burton Lake, Antarctica. Polar Biol. 10:261-264.

12. Gauthier, G., M. Gauthier, and R. Christen. 1995. Phylogenetic analysis of the genera Alteromonas, Shewanella, and Moritella using genes coding for small-subunit rRNA sequences and division of the genus Alteromonas into two genera, Alteromonas (emended) and Pseudoalteromonas gen. nov., and proposal of twelve new species combinations. Int. J. Syst. Bacteriol. 45:755761.

13. Hungate, R. E. 1968. A roll tube method for cultivation of strict anaerobes Methods Microbiol. 3B:117-132.

14. Huss, V. A. R., H. Festl, and K. H. Schleifer. 1983. Studies on the spectrophotometric determination of DNA hybridization from renaturation rates. Syst. Appl. Microbiol. 4:184-192.

15. Jensen, M. J., B. M. Tebo, P. Baumann, M. Mandel, and K. H. Nealson.
1980. Characterization of Alteromonas hanedai (sp. nov.), a non-fermentative luminous species of marine origin. Curr. Microbiol. 3:311-315.

16. Kato, C., N. Masui, and K. Horikoshi. 1995. Isolation and properties of barophilic and barotolerant bacteria from deep-sea mud. Biodivers. Conserv. 4:1-9.

17. Kato, C., T. Sato, and K. Horikoshi. 1996. Properties of obligately barophilic bacteria isolated from samples of deep-sea sediment from the Izu-Bonin trench. J. Mar. Biotechnol. 4:96-99.

18. Leifson, E. 1963. Determination of carbohydrate metabolism of marine bacteria. J. Bacteriol. 85:1183-1184.

19. Long, H. F., and B. W. Hammer. 1941. Classification of organisms important in dairy products. III. Pseudomonas putrefaciens. Iowa Agric. Exp. Stn. Res. Bull. 285:176-195.

20. Lovely, D. R. 1993. Dissimilatory metal reduction. Annu. Rev. Microbiol. 47:263-290.

21. Lovely, D. R., and E. J. P. Phillips. 1986. Organic matter mineralization with reduction of ferric iron in anaerobic sediments. Appl. Environ. Microbiol. 51:683-689.

22. MacDonell, M. T., and R. R. Colwell. 1985. Phylogeny of the Vibrionaceae, and recommendation for two new genera, Listonella and Shewanella. Syst. Appl. Microbiol. 6:171-182.

23. Marmur, J., and P. Doty. 1962. Determination of the base composition of deoxyribonucleic acid from its thermal denaturation temperature. J. Mol. Biol. 5:109-118.

24. Meinkoth, J., and G. Wahl. 1984. Hybridization of nucleic acids immobilized on solid supports. Anal. Biochem. 138:267-284.

25. Molin, G., and A. Ternström. 1986. Phenotypically based taxonomy of psychrotrophic Pseudomonas isolated from spoiled meat, water, and soil. Int. J. Syst. Bacteriol. 36:257-274.

26. Moser, D. P., and K. H. Nealson. 1996. Growth of the facultative anaerobe Shewanella putrefaciens by elemental sulfur reduction. Appl. Environ. Microbiol. 62:2100-2105.

27. Moule, A. L., and S. G. Wilkinson. 1987. Polar lipids, fatty acids and isoprenoid quinones of Alteromonas putrefaciens (Shewanella putrefaciens). Syst. Appl. Microbiol. 9:192-198.

28. Nichols, D. S., P. D. Nichols, and T. A. McMeekin. 1993. Polyunsaturated fatty acids in Antarctic bacteria. Antarct. Sci. 5:149-160.

29. Nichols, D. S., P. D. Nichols, and T. A. McMeekin. 1995. Ecology and physiology of psychrophilic bacteria from Antarctic saline lakes and sea ice. Sci. Prog. 78:311-347.

30. Nichols, D. S., and N. J. Russell. 1996. Fatty acid adaptation in an Antarctic bacterium-changes in primer utilization. Microbiology 142:747-754.

31. Nichols, P. D., J. B. Guckert, and D. C. White. 1986. Determination of monounsaturated fatty acid double-bond position and geometry for microbial monocultures and complex consortia by capillary GC-MS of their dimethyldisulphide adducts. J. Microbiol. Methods 5:49-55.

32. Nozue, H., T. Hayashi, Y. Hashimoto, T. Ezaki, K. Hamasaki, K. Ohwada, and Y. Terawaki. 1992. Isolation and characterization of Shewanella alga from human clinical specimens and emendation of the description of $S$. alga Simidu et al., 1990, 335. Int. J. Syst. Bacteriol. 42:628-634.

33. Overmann, J., and N. Pfennig. 1989. Pelodictyon phaeoclathratiforme sp. nov., a new brown-colored member of the Chlorobiaceae forming net-like colonies. Arch. Microbiol. 152:401-406.

34. Owen, R. J., R. M. Legros, and S. P. Lapage. 1978. Base composition, size, and sequence similarities of genome deoxyribonucleic acids from clinical isolates of Pseudomonas putrefaciens. J. Gen. Microbiol. 104:127-138.

35. Picardal, F., R. G. Arnold, and B. B. Huey. 1995. Effects of electron donor and acceptor conditions on reductive dehalogenation of tetrachloromethane by Shewanella putrefaciens 200. Appl. Environ. Microbiol. 61:8-12.

36. Ratkowsky, D. A., R. K. Lowry, T. A. McMeekin, A. N. Stokes, and R. E. Chandler. 1983. Model for bacterial growth throughout the entire biokinetic range. J. Bacteriol. 154:1222-1226.

37. Rosello-Mora, R. A., F. Caccavo, Jr., K. Osterlehner, N. Springer, S. Spring, D. Schüler, W. Ludwig, R. Amann, M. Vanncannevt, and K. H. Schleifer. 1994. Isolation and taxonomic characterization of a halotolerant, facultatively iron-reducing bacterium. Syst. Appl. Microbiol. 17:569-573.

38. Rossello-Mora, R. A., W. Ludwig, P. Kämpfer, R. Amann, and K. H. Schleifer. 1995. Ferrimonas balearica gen. nov., a new marine facultative $\mathrm{Fe}(\mathrm{III})$ reducing bacterium. Syst. Appl. Microbiol. 18:196-202.

39. Simidu, U., K. Kita-Tsukamoto, T. Yasumoto, and M. Yotsu. 1990. Taxonomy of four marine bacterial strains that produce tetrodotoxin. Int. J. Syst. Bacteriol. 40:331-336.

40. Sly, L. I., L. L. Blackall, P. C. Kraat, T. Tian-Shen, and V. Sangkhobol. 1986. The use of second derivative plots for the determination of mol\% guanine plus cytosine of DNA by the thermal denaturation method. J. Microbiol. Methods 5:139-156.

41. Smibert, R. M., and N. R. Krieg. 1994. Phenotypic characterization, p. 611-654. In P. Gerhardt, R. G. E. Murray, W. A. Wood, and N. R. Krieg (ed.), Methods for general and molecular microbiology. American Society for Microbiology, Washington, D.C.

42. Stenström, I.-M., and G. Molin. 1990. Classification of the spoilage flora of 
fish, with special reference to Shewanella putrefaciens. J. Appl. Bacteriol. 68:601-618.

43. Weiner, R. M., V. E. Coyne, P. Brayton, P. West, and S. F. Raiken. 1988. Alteromonas colwelliana sp. nov., an isolate from oyster habitats. Int. J. Syst. Bacteriol. 38:240-244.

44. West, P. A., and R. R. Colwell. 1984. Identification and classification of the
Vibrionaceae-an overview, p. 285-363. In R. R. Colwell (ed.), Vibrios in the environment. John Wiley \& Sons, New York, N.Y.

45. Widdel, F., and F. Bak. 1992. Gram-negative mesophilic sulfate-reducing bacteria, p. 3352-3378. In A. Balows, H. G. Trüper, M. Dworkin, W. Harder, and K. H. Schleifer (ed.), The prokaryotes, 2nd ed. Springer-Verlag, Berlin, Germany, 